\title{
Hubungan Persekitaran Sekolah dan Guru dengan Amalan Akhlak Murid Sekolah Menengah Malaysia
}

\author{
Relations of School Environment and Teachers to Islamic Morals Practices of Malaysian \\ Secondary School Students
}

\author{
AB HALIM TAMURI \& AHMAD MUNAWAR ISMAIL ${ }^{1}$
}

\begin{abstract}
This article examines the moral practice of secondary school students in Malaysia and their perception towards the school environment and the teachers of Islamic education. This article is part of the findings of a study that has used the survey as a method of data collection. The questionnaires were distributed to the students in the form four and lower six of secondary schools in Malaysia. They were selected based on the of multi stages cluster sampling. A total of 3,262 students were involved in answering the questionnaires. SPSS software has been used to analyze the data. It can be concluded that, the Islamic practice of Muslim students in secondary schools is categorized as 'a high level of religious practice' and their perception on school environment and Islamic education teachers also is high. This study also shows that there is a significant correlation between the Islamic moral practices of students and their perceptions of the school environment, and between Islamic education teachers.
\end{abstract}

Key words: Islamic morals, Islamic education, school environment, students' perception

Dalam konteks pelaksanaan Pendidikan Islam semasa di Malaysia, mata pelajaran Pendidikan Islam dalam kurikulum pendidikan kebangsaan adalah salah satu mata pelajaran yang diwajibkan oleh Kementerian Pendidikan Malaysia (KPM) kepada murid-murid Islam pada peringkat Kurikulum Bersepadu Sekolah Rendah (KBSR) dan Kurikulum Bersepadu Sekolah Menengah (KBSM). Pada peringkat KBSM, mata pelajaran ini mengandungi kompenan Tilawah al-Quran, Akidah, Ibadah, Akhlak dan Tamadun (KPM 2002). Dalam Kurikulum Standard Sekolah Rendah (KSSR) yang diperkenalkan selepas itu, mata pelajaran pendidikan Islam adalah mata pelajaran teras yang wajib diambil oleh semua murid beragama Islam. Sukatan pelajaran pendidikan Islam dalam KSSR mencakupi semua asas yang diperlukan oleh murid Islam iaitu tilawah al-Quran, kefahaman, tajwid, hadis, akidah, ibadah, sirah, adab dan jawi (KPM 2015a). Untuk peringkat KSSM pula, sukatan pelajaran yang ditawarkan meliputi komponen asas dalam pendidikan Islam iaitu al-Quran, hadis, akidah, fiqh, sirah dan tamadun Islam serta akhlak Islamiah (KPM 2015b). Ini adalah usaha untuk memenuhi hasrat Falsafah Pendidikan Kebangsaan (FPK) yang telah diwartakan sebagi dokumen rasmi kerajaan, iaitu dalam Akta Pendidikan 1996 (Akta 550, KPM) yang dengan tegas menyebut bahawa (KPM, 2015a; KPM2015b):

\footnotetext{
"Pendidikan di Malaysia adalah suatu usaha yang berterusan ke arah memperkembangkan lagi potensi individu secara menyeluruh dan bersepadu untuk mewujudkan insan yang seimbang dan harmonis dari segi intelek, rohani, emosi dan jasmani berdasarkan kepercayaan
}

\footnotetext{
${ }^{1}$ Ab Halim Tamuri, Ph. D.* (corresponding author) Professor at Centre of Education Leadership and Policy, Faculty of Education, Universiti Kebangsaan Malaysia, 43600 BANGI, Selangor, Malaysia. Email: abhalim@ukm.edu.my; Ahmad Munawar Ismail, Ph. D., Assoc. Prof. at Research Centre for Theology and Philosophy, Faculty of Islamic Studies, Universiti Kebangsaan Malaysia, 43600 BANGI, Selangor, Malaysia. Email: munawar@ukm.edu.my.
} 
dan kepatuhan kepada Tuhan. Usaha ini adalah bertujuan untuk melahirkan warganegara Malaysia yang berilmu pengetahuan, berketerampilan, berakhlak mulia, bertanggungjawab dan berkeupayaan mencapai kesejahteraan diri serta memberikan sumbangan terhadap keharmonian dan kemakmuran keluarga, masyarakat dan negara."

Falsafah tersebut digubal berdasarkan kepada matlamat yang mahu dicapai serta hasrat dan falsafah pendidikan yang unggul. FPK menganjurkan konsep pendidikan sepadu, dengan memautkan ilmu yang bercorak naqliah dan mutlak untuk kehidupan sebenar dan menguasai pelbagai kemahiran yang canggih bagi kehidupan seharian manusia (Zarin \& Ab. Halim 2007; Noor Hisham 2018). Perkara yang diberikan tumpuan ialah melahirkan insan yang baik dengan salah satu kriterianya berakhlak mulia. Selain itu, ini selaras dengan matlamat utama Falsafah Pendidikan Islam untuk menghasilkan Muslim yang berilmu, beriman, berketermpilan, beramal soleh dan berakhlak mulia berdasarkan al-Quran dan al-Sunnah ke arah menjadi hamba dan khalifah Allah yang bertakwa dan menyumbang ke arah meningkatkan tamadun bangsa dan negara. Matlamat Pendidikan Islam dalam KSSM telah dinyatakan seperti berikut (KPM 2015b; KPM 2016):

\begin{abstract}
"Matlamat KSSM Pendidikan Islam adalah untuk membina dan membentuk hamba dan khalifah Allah SWT yang berilmu, beriman, bertaqwa, beramal soleh, berakhlak mulia dan berketerampilan berdasarkan al-Quran dan al-Sunnah serta menyumbang ke arah mempertingkatkan tamadun bangsa dan negara serta kesejahteraan alam demi mencapai kesejahteraan dunia dan akhirat.".
\end{abstract}

\title{
Pendidikan dan Praktik Akhlak dalam Kehidupan
}

Secara umumnya, tumpuan utama sistem pendidikan di Malaysia ialah untuk melahirkan warga Malaysia yang baik dan dapat menyumbangkan kepada pembangunan negara seperti termaktub dalam Falsafah Pendidikan Kebangsaan yang diwartakan melalui Akta Pendidikan 1996 itu. Minda kelas pertama tidak akan terbentuk dan wujud di dalam persekitaran yang mengutamakan hiburan semata-mata tanpa memperkasakan nilai kerohanian di dalam jiwa (Ahmad Munawar et. al. 2012; Marhaiza et. al. 2015). Dalam konteks pendidikan formal, aspek ini diberikan tumpuan melalui komponen pendidikan akhlak dalam mata pelajaran pendidikan Islam diperingkat sekolah rendah dan menengah.

Dalam pelaksanaan Pendidikan Islam di sekolah, terdapat beberapa isu yang dikenal pasti antaranya aspek yang perlu dipertingkatkan dalam pengajaran dan pembelajaran Pendidikan Islam yang berkaitan pembinaan akhlak pelajar (Azhar 2010; Asmawati 2003; Ab. Halim 2000; Kementerian Pendidikan Malaysia 1996) Bagi mengatasi masalah tersebut, kurikulum Pendidikan Islam telah digubal dan disemak semula oleh pihak KPM. Sebagai contoh, Pendidikan Akhlak Islamiyyah diperkenalkan sebagai salah satu komponen yang utama dalam mata pelajaran Pendidikan Islam menggantikan Bahagian Sifat dan Cara Hidup Islam. Selepas itu, sukatan pelajaran Pendidikan Islam disemak semula buat kali keduanya kerana dikatakan kurikulum Pendidikan Islam khususnya komponen pendidikan akhlak kurang berkesan dan terdapatnya peningkatan keruntuhan akhlak pelajar Islam (Asmawati 2003). Pendidikan akhlak dalam mata pelajaran pendidikan telah dipertingkatkan dengan semakan perubahan sukatan mata pelajaran dan pendekatan pengajarannya (Asmawati 2003). Komponen ini dinamakan dengan Adab dan Akhlak Islamiyyah dan mula dilaksanakan secara berperingkat-peringkat pada tahun 2003 dengan dimulai pada Tingkatan Satu dan Empat sepenuhnya pada tahun 2005 (Asmawati 2003). Pada tahun 2017, satu sukatan baru mata pelajaran pendidikan Islam dalam KSSM telah diperkenalkan melalui Kurikulum Standard Sekolah Menengah Pendidikan Islam (KPM 2015b). Kurikulum Standard Sekolah Menengah (KSSM) yang dilaksanakan secara berperingkat mulai tahun 2017 ini menggantikan Kurikulum Bersepadu Sekolah Menengah (KBSM) yang mula dilaksanakan pada tahun 1989 (KPM 2018). Dalam konteks pendidikan akhlak, sukatan baru Pendidikan Islam KSSM ini dikenali sebagai Akhlak Islamiah. Objektif utama 
pelaksanaan sukatan Akhlak Islamiah ialah untuk merumus kefahaman akhlak Islamiah dan mengamalkan serta menghayatinya dalam kehidupan (KPM 2015b; KPM 2018).

Sebagaimana kurikulum-kurikulum Pendidikan Islam sebelum ini, kandungan kurikulum Pendidikan Islam KSSM juga memberikan tumpuan kepada dua komponen utama dalam akhlak iaitu akhlak dengan Allah, dan akhlak sesama manusia dan makhluk lain. Secara umumnya kandungan pendidikan akhlak dalam kurikulum yang ditawarkan adalah merangkumi semua komponen akhlak sebagaimana yang diditilkan oleh Darraz (1987). Melalui pelaksanaan KBSM diperingkat sekolah menengah, pendedahan pendidikan akhlak bukan sahaja tertumpu dalam satu bahagian daripada mata pelajaran Pendidikan Islam iaitu Akhlak Islamiyyah semata-mata, tetapi juga turut diaplikasikan secara gabung jalin dalam pengajaran bidang-bidang lain dalam pendidikan Islam serta diterapkan juga mata pelajaran lain dan juga aktiviti-aktiviti kokurikulum di sekolah (Kementerian Pendidikan Malaysia 1990). Walaupun kadangkala ianya menggunakan istilah nilai murni atau nilai moral, tetapi matlamatnya adalah untuk melahirkan generasi berperibadi mulia (Wan Hasmah 1993). Malah dalam KSSM, kurikulum ini dibina berasaskan enam tunjang utama iaitu (KPM 2018):

“... Komunikasi Kerohanian, Sikap dan Nilai; Kemanusiaan; Keterampilan Diri; Perkembangan Fizikal dan Estetika; serta Sains dan Teknologi. Enam tunjang tersebut merupakan domain utama yang menyokong antara satu sama lain dan disepadukan dengan pemikiran kritis, kreatif dan inovatif. Kesepaduan ini bertujuan membangunkan modal insan yang menghayati nilai-nilai murni berteraskan keagamaan, berpengetahuan, berketerampilan, berpemikiran kritis dan kreatif serta inovatif".

Umumnya, terdapat berbagai bentuk cabaran yang perlu dihadapi dalam aspek pengamalan akhlak kalangan murid. Satu aspek utama kini ialah cabaran media sosial yang terbuka dengan budaya negatif berasaskan kepada keseronokan, pakaian dan budaya hidup bebas yang mengetepikan nilai-nilai Islam. Penggunaan media sosial seperti Facebook, YouTube, Instragram, Whatsapp, TikTok, Telegram, Wechat menjadi semakin popular di Malaysia menjadi satu budaya baru yang akan memberi kesan dalam kehidupan mereka. Faktor-faktor di luar sekolah seperti ibu bapa, rakan sebaya, masyarakat serta undang-undang turut mempunyai pengaruh terhadap pembangunan dan amalan akhlak murid (Ahmad Munawar et. al. 2012).

Kini perkembangaan revolusi industri 4.0, berbanding dengan generasi terdahulu, proses sosialisasi dan kematangan pada masa kini berlaku dengan keadaan yang berbeza-beza berdasarkan kepada faktor persekitaran yang ada. Pada asasnya, gaya kehidupan remaja Islam tidak boleh disamakan dengan gaya hidup remaja Barat kerana remaja Muslim perlu dididik dengan nilai-nilai keislaman dan yang berteraskan kepada tauhid dan akhlak Islam (Ab. Halim 2015). Selain faktor ibubapa dan masyarakat, aspek pencapaian akademik, pengalaman tinggal di asrama, dan kemudahan peranti komunikasi dan aliran sekolah memberikan kesan kepada amalan akhlak murid (Ahmad Munawar \& Wan Kamal 2012). Menurut kajian Rohana et. al. (2016) tahap pendidikan keagamaan yang dilalui oleh anak secara tidak formal bersama ibu bapa berada pada tahap tinggi, majoriti responden kajian berpendapat bahawa tingkah-laku ibu bapa menjadi contoh kepada akhlak Islam mereka. Seterusnya, kajian Rozmi et. al. (2017) mendapati adanya hubungan sosio-demografi remaja dan faktor keterlibatan seperti keluarga (pengawasan ibu bapa, pengurusan keluarga, pelekatan keluarga, tekanan keprihatinan keluarga, tekanan kehidupan), faktor persekitaran sosial (penglibatan aktiviti di sekolah, aktiviti berisiko di sekolah, komuniti, pelindung persekitaran sekolah, komuniti dan rakan sebaya) dan tingkah laku berisiko salah guna bahan. Dalam melahirkan generasi yang tinggi keupayaan kognitifnya, penuh dengan nilai murni dan kuat pegangan ajaran agamanya, maka guru perlu bertindak sebagai penggerak kepada transformasi pendidikan negara (Noornajihan \& Ab. Halim 2012). Sehubungan itu, guru dan sekolah merupakan pengaruh yang paling penting dalam perkembangan murid dari segi fizikal, intelek, emosi dan sosialnya. Guru yang bersifat penyayang dan cekap menguruskan aktiviti pengajaran pembelajaran dalam bilik darjah serta iklim sekolah yang kondusif serta dilengkapi dengan kemudahan pengajaran pembelajaran akan membantu perkembangan 
kognitif, efektif dan psikomotor murid (Ahmad Munawar \& Wan Kalam 2012). Maka kajian ini akan melihat perbezaan tahap amalan akhlak murid berdasarkan beberapa pembolehubah yang berkaitan dengan sistem persekolahan iaitu tingkatan, pengalaman tinggal di asrama, internet, telefon bimbit, peranti telekomunikasi seperti komputer riba, aliran sekolah dan pencapaian pendidikan Islam dalam Penilaian Menengah Rendah (PMR) memberikan perbezaan kepada amalan akhlak dalam kalangan murid atau sebaliknya.

\section{Metodologi Kajian}

Kajian ini menggunakan kaedah tinjauan (survey) sebagai instrumen utama pengumpulan data. Dalam kajian ini, tumpuan diberikan kepada maklum balas dan persepsi murid terhadap persekitaran sekolah dan guru pendidikan Islam yang mengajar mereka. Soal selidik digunakan untuk mendapatkan data daripada sampel yang telah dipilih secara rawak bagi mewakili populasi yang dipilih dari kalangan murid sekolah menengah di Malaysia. Instrumen ini telah melalui proses kesahan muka dan kesahan kandungan termasuk semakan daripada 30 orang pakar dan guru-guru pendidikan Islam yang berpengalaman di dalam 4 bengkel yang dijalankan. Kajian rintis telah melibatkan seramai 99 orang murid tingkatan empat daripada pelbagai aliran akademik telah dipilih secara rawak dari dua buah sekolah di negeri Selangor, satu mewakili kawasan luar bandar, dan satu mewakili kawasan bandar. Hasil analisis dijalankan, didapati nilai pekali alpha bagi tahap kebolehpercayaan borang soal selidik yang digunakan adalah tinggi iaitu iaitu 0.877 bagi pengamalan akhlak dan 0.869 persekitaran sosial. Populasi kajian ini terdiri daripada murid tingkatan empat dan enam rendah daripada pelbagai sekolah menengah di Malaysia iaitu sekolah menengah kebangsaan (SMK), sekolah berasrama penuh (SBP), sekolah menengah kebangsaan agama (SMKA) dan sekolah menengah teknik (SMT). Kaedah multi stage cluster sampling telah digunakan untuk memilih murid sebagai sampel kajian ini (Burn 2000; Cohen et. al. 2000; Ary et. al. 1990). Unit-unit sampel ini dipilih secara rawak daripada kawasankawasan sampel berdasarkan sistem zon, negeri, daerah dan sekolah iaitu, Zon Utara (Kedah, Pulau Pinang dan Perlis) -550 responden; Zon Selatan (Johor, Melaka dan Negeri Sembilan) -567 responden; Zon Timur (Kelantan, Terengganu dan Pahang) -570 responden; Zon Tengah (Perak, Selangor dan Wilayah Persekutuan) -539 responden; Sabah (Zon Utara, Tenggara dan Selatan); 538 responden dan Sarawak (Zon Utara, Tengah dan Selatan) - 498 responden. Keseluruhan 3,262 orang murid terlibat dalam kajian ini.

\section{Dapatan Kajian dan Perbincangan}

Jadual berikut melaporkan dapatan kajian yang berkaitan dengan tahap amalan akhlak murid Islam dalam kehidupan seharian mereka yang diperolehi daripada borang soal selidik yang diedarkan.

Jadual 1: Tahap Amalan Akhlak Murid-Murid

\begin{tabular}{|c|c|c|c|c|c|c|c|c|}
\hline \multirow{2}{*}{ Bil } & \multirow{2}{*}{ AMALAN AKHLAK } & \multicolumn{5}{|c|}{ KEKERAPAN DAN PERATUSAN } & \multirow{2}{*}{ MIN } & \multirow{2}{*}{ Sp. } \\
\hline & & STS & TS & KS & $\mathrm{S}$ & SS & & \\
\hline 1 & $\begin{array}{l}\text { Saya berfikir dan memerhati } \\
\text { tanda-tanda kebesaran Allah } \\
\text { pada diri dan alam pada setiap } \\
\text { masa. }\end{array}$ & $\begin{array}{c}19 \\
(1 \%)\end{array}$ & $\begin{array}{c}28 \\
(1 \%)\end{array}$ & $\begin{array}{c}391 \\
(12 \%)\end{array}$ & $\begin{array}{c}1743 \\
(53 \%)\end{array}$ & $\begin{array}{c}1069 \\
(33 \%)\end{array}$ & 4.17 & 0.71 \\
\hline 2 & $\begin{array}{l}\text { Saya berdoa untuk } \\
\text { mengharapkan kasih sayang } \\
\text { Allah. }\end{array}$ & $\begin{array}{c}12 \\
(0 \%)\end{array}$ & $\begin{array}{c}22 \\
(1 \%)\end{array}$ & $\begin{array}{c}154 \\
(5 \%)\end{array}$ & $\begin{array}{c}1205 \\
(37 \%)\end{array}$ & $\begin{array}{c}1862 \\
(57 \%)\end{array}$ & 4.50 & 0.65 \\
\hline 3 & $\begin{array}{l}\text { Saya sentiasa berhati-hati } \\
\text { dalam setiap tindakan kerana } \\
\text { takut kepada Allah. }\end{array}$ & $\begin{array}{c}11 \\
(0 \%)\end{array}$ & $\begin{array}{c}37 \\
(1 \%)\end{array}$ & $\begin{array}{c}407 \\
(12 \%)\end{array}$ & $\begin{array}{c}1494 \\
(46 \%)\end{array}$ & $\begin{array}{c}1303 \\
(40 \%)\end{array}$ & 4.24 & 0.74 \\
\hline
\end{tabular}


4 Saya patuh kepada hukum Islam walaupun terpaksa meninggalkan perbuatan kegemaran saya.

5* Saya mendirikan solat hanya sekadar melengkapkan rutin harian.

6* Saya meninggalkan ajaran Islam apabila ia tidak sesuai dengan kemahuan saya.

7* $\quad$ Saya percaya ada kuasa lain selain Allah yang boleh menyembuhkan penyakit manusia.

8 Saya perlu melaksanakan perintah Allah dan menjauhi larangan-Nya dengan hati yang terbuka.

9 Saya tidak melakukan perkaraperkara yang menghampiri zina.

10 Saya mengucapkan salam apabila bertemu guru.

11 Saya mengucapkan salam apabila bertemu rakan-rakan.

12 Saya suka beramal dengan sunnah nabi.

13 Saya memelihara solat fardu lima waktu.

14* Saya melakukan hubungan seks.

15 Saya sentiasa memelihara pandangan saya dari melihat aurat wanita (bagi lelaki) / aurat lelaki (bagi wanita).

16 Saya sentiasa meyakini kewujudan malaikat.

17 Saya percaya semua perbuatan baik atau buruk yang kita lakukan dicatat oleh malaikat yang ditugaskan oleh Allah.

18* Saya mengambil sesuatu barang walaupun ia bukan milik saya.

19* Saya bercakap tentang keaiban/keburukan orang lain tanpa pengetahuan teman berkenaan.

20 Saya segera bertaubat jika melakukan dosa.

21 Saya yakin tentang kewujudan syaitan.

$\begin{array}{ccccccc}48 & 88 & 625 & 1459 & 1030 & 4.03 & 0.87 \\ (1 \%) & (3 \%) & (19 \%) & (45 \%) & (32 \%) & & \end{array}$

$\begin{array}{ccccccc}1450 & 822 & 666 & 246 & 62 & 4.03 & 1.06 \\ (44 \%) & (25 \%) & (20 \%) & (6 \%) & (2 \%) & & \end{array}$

$\begin{array}{lllllll}2372 & 569 & 187 & 78 & 46 & 4.58 & 0.82\end{array}$

$(73 \%) \quad(17 \%) \quad(6 \%) \quad(2 \%) \quad(1 \%)$

$\begin{array}{lllllll}2626 & 413 & 90 & 42 & 77 & 4.68 & 0.80\end{array}$

$(80 \%) \quad(13 \%) \quad(3 \%) \quad(1 \%) \quad(2 \%)$

$\begin{array}{lllllll}40 & 17 & 57 & 732 & 2412 & 4.67 & 0.66\end{array}$

$(1 \%) \quad(0 \%) \quad(2 \%) \quad(22 \%) \quad(74 \%)$

$\begin{array}{lllllll}82 & 121 & 517 & 1149 & 1386 & 4.12 & 0.97\end{array}$

$(2 \%) \quad(4 \%) \quad(16 \%) \quad(35 \%) \quad(42 \%)$

$\begin{array}{lllllll}8 & 13 & 119 & 1191 & 1927 & 4.54 & 0.61\end{array}$

$(0 \%) \quad(0 \%) \quad(4 \%) \quad(36 \%) \quad(59 \%)$

$\begin{array}{lllllll}26 & 78 & 617 & 1558 & 974 & 4.04 & 0.81\end{array}$

$(1 \%) \quad(2 \%) \quad(19 \%) \quad(49 \%) \quad(30 \%)$

$\begin{array}{lllllll}12 & 49 & 538 & 1694 & 962 & 4.09 & 0.74\end{array}$

$(0 \%) \quad(1 \%) \quad(16 \%) \quad(52 \%) \quad(29 \%)$

$\begin{array}{lllllll}53 & 95 & 535 & 1178 & 1390 & 4.15 & 0.91\end{array}$

$(2 \%) \quad(3 \%) \quad(16 \%) \quad(36 \%) \quad(43 \%)$

$\begin{array}{lllllll}2768 & 282 & 90 & 52 & 57 & 4.74 & 0.74\end{array}$

$(85 \%) \quad(9 \%) \quad(3 \%) \quad(2 \%) \quad(2 \%)$

$\begin{array}{lllllll}143 & 190 & 703 & 1278 & 940 & 3.82 & 1.05\end{array}$

$\begin{array}{lllll}(4 \%) & (6 \%) & (22 \%) & (39 \%) & (29 \%)\end{array}$

$\begin{array}{lllllll}10 & 10 & 51 & 570 & 2615 & 4.78 & 0.51\end{array}$

$(0 \%) \quad(0 \%) \quad(2 \%) \quad(17 \%) \quad(80 \%)$

$\begin{array}{lllllll}13 & 5 & 13 & 254 & 2974 & 4.89 & 0.40\end{array}$

$(0 \%) \quad(0 \%) \quad(0 \%) \quad(8 \%) \quad(91 \%)$

$\begin{array}{lllllll}1702 & 745 & 528 & 226 & 58 & 4.17 & 1.04\end{array}$

$(52 \%) \quad(23 \%) \quad(16 \%) \quad(7 \%) \quad(2 \%)$

$\begin{array}{lllllll}1163 & 711 & 767 & 512 & 100 & 3.71 & 1.19\end{array}$

$(36 \%) \quad(22 \%) \quad(23 \%) \quad(16 \%) \quad(3 \%)$

$\begin{array}{ccccccc}34 & 88 & 675 & 1452 & 1005 & 4.01 & 0.85 \\ (1 \%) & (3 \%) & (21 \%) & (44 \%) & (31 \%) & & \\ 54 & 29 & 154 & 953 & 2066 & 4.52 & 0.77 \\ (2 \%) & (1 \%) & (5 \%) & (29 \%) & (63 \%) & & \end{array}$


22 Saya yakin segala bisikan ke arah kejahatan datang dari syaitan.

23 Membaca al-Quran dapat menenangkan hati saya.

24 Saya berasa sedih apabila alQuran dihina dan dibakar.

25 Saya gemar mendengar lagulagu rentak terkini berbanding bacaan al-Quran.

26* Kita boleh untuk TIDAK mengikut ajaran al-Quran.

27 Saya melakukan sesuatu urusan mengikut peraturan yang ada.

28 Saya membeli pakaian atau makanan sekadar yang diperlukan.

29 Saya mempertahankan prinsip agama walaupun menghadapi pelbagai ancaman.

30* Saya TIDAK merasa kesal apabila saya meninggalkan solat.

31* Kebahagiaan di dunia adalah matlamat hidup saya.

32 Saya berfikir tentang pembalasan yang akan saya terima di akhirat.

33* Saya TIDAK merasa apa-apa kesan dalam jiwa apabila berlaku sesuatu bencana alam seperti tsunami.

34 Saya mengajak rakan-rakan saya melakukan kebaikan.

35 Saya takutkan azab Allah di dunia dan di akhirat.

36 Saya mencegah rakan-rakan dari melakukan perbuatan maksiat.

37 Halangan dalam hidup tidak menghalang usaha saya untuk mencapai cita-cita.

38 Saya mengingatkan diri saya bahawa segala yang berlaku ada hikmah dari Allah.

39* Saya merasakan segala usaha yang gagal adalah sia-sia.

40 Saya membalas cacian dengan senyuman dan doa.

41 Saya menghormati kebolehan

\begin{tabular}{|c|c|c|c|c|c|c|}
\hline $\begin{array}{c}38 \\
(1 \%)\end{array}$ & $\begin{array}{c}34 \\
(1 \%)\end{array}$ & $\begin{array}{c}132 \\
(4 \%)\end{array}$ & $\begin{array}{c}742 \\
(23 \%)\end{array}$ & $\begin{array}{c}2310 \\
(71 \%)\end{array}$ & 4.61 & 0.72 \\
\hline $\begin{array}{c}5 \\
(0 \%)\end{array}$ & $\begin{array}{c}5 \\
(0 \%)\end{array}$ & $\begin{array}{c}35 \\
(1 \%)\end{array}$ & $\begin{array}{c}520 \\
(16 \%)\end{array}$ & $\begin{array}{c}2694 \\
(83 \%)\end{array}$ & 4.81 & 0.45 \\
\hline $\begin{array}{c}36 \\
(1 \%)\end{array}$ & $\begin{array}{c}27 \\
(1 \%)\end{array}$ & $\begin{array}{c}52 \\
(2 \%)\end{array}$ & $\begin{array}{c}378 \\
(12 \%)\end{array}$ & $\begin{array}{c}2756 \\
(84 \%)\end{array}$ & 4.78 & 0.62 \\
\hline $\begin{array}{c}767 \\
(23 \%)\end{array}$ & $\begin{array}{c}564 \\
(17 \%)\end{array}$ & $\begin{array}{c}1106 \\
(34 \%)\end{array}$ & $\begin{array}{c}678 \\
(21 \%)\end{array}$ & $\begin{array}{c}137 \\
(4 \%)\end{array}$ & 2.64 & 1.17 \\
\hline $\begin{array}{c}2628 \\
(81 \%)\end{array}$ & $\begin{array}{c}315 \\
(10 \%)\end{array}$ & $\begin{array}{c}135 \\
(4 \%)\end{array}$ & $\begin{array}{c}70 \\
(2 \%)\end{array}$ & $\begin{array}{c}101 \\
(3 \%)\end{array}$ & 4.63 & 0.90 \\
\hline $\begin{array}{c}63 \\
(2 \%)\end{array}$ & $\begin{array}{c}84 \\
(3 \%)\end{array}$ & $\begin{array}{c}625 \\
(19 \%)\end{array}$ & $\begin{array}{c}1659 \\
(51 \%)\end{array}$ & $\begin{array}{c}821 \\
(25 \%)\end{array}$ & 3.95 & 0.85 \\
\hline $\begin{array}{c}26 \\
(1 \%)\end{array}$ & $\begin{array}{c}75 \\
(2 \%)\end{array}$ & $\begin{array}{c}496 \\
(15 \%)\end{array}$ & $\begin{array}{c}1615 \\
(49 \%)\end{array}$ & $\begin{array}{c}1043 \\
(\%)\end{array}$ & 4.10 & 0.79 \\
\hline $\begin{array}{c}41 \\
(1 \%)\end{array}$ & $\begin{array}{c}38 \\
(2 \%)\end{array}$ & $\begin{array}{c}255 \\
(8 \%)\end{array}$ & $\begin{array}{c}1422 \\
(44 \%)\end{array}$ & $\begin{array}{c}1496 \\
(46 \%)\end{array}$ & 4.32 & 0.77 \\
\hline $\begin{array}{c}1914 \\
(59 \%)\end{array}$ & $\begin{array}{c}626 \\
(19 \%)\end{array}$ & $\begin{array}{c}487 \\
(15 \%)\end{array}$ & $\begin{array}{c}156 \\
(5 \%)\end{array}$ & $\begin{array}{c}70 \\
(2 \%)\end{array}$ & 4.28 & 1.02 \\
\hline $\begin{array}{l}957 \\
(\%)\end{array}$ & $\begin{array}{l}609 \\
(\%)\end{array}$ & $\begin{array}{l}996 \\
(\%)\end{array}$ & $\begin{array}{l}415 \\
(\%)\end{array}$ & $\begin{array}{l}273 \\
(\%)\end{array}$ & 3.48 & 1.26 \\
\hline $\begin{array}{c}45 \\
(1 \%)\end{array}$ & $\begin{array}{c}31 \\
(1 \%)\end{array}$ & $\begin{array}{c}105 \\
(3 \%)\end{array}$ & $\begin{array}{c}1085 \\
(33 \%)\end{array}$ & $\begin{array}{c}1981 \\
(61 \%)\end{array}$ & 4.51 & 0.73 \\
\hline $\begin{array}{c}1904 \\
(58 \%)\end{array}$ & $\begin{array}{c}728 \\
(22 \%)\end{array}$ & $\begin{array}{c}384 \\
(12 \%)\end{array}$ & $\begin{array}{c}130 \\
(4 \%)\end{array}$ & $\begin{array}{c}109 \\
(3 \%)\end{array}$ & 4.29 & 1.04 \\
\hline
\end{tabular}

$\begin{array}{ccccccc}19 & 26 & 268 & 1632 & 1310 & 4.29 & 0.70 \\ (1 \%) & (1 \%) & (8 \%) & (50 \%) & (40 \%) & & \\ 9 & 7 & 23 & 517 & 2695 & 4.81 & 0.46 \\ (0 \%) & (0 \%) & (1 \%) & (16 \%) & (83 \%) & & \\ 24 & 45 & 470 & 1447 & 1266 & 4.19 & 0.78 \\ (1 \%) & (1 \%) & (14 \%) & (44 \%) & (39 \%) & & \end{array}$

$\begin{array}{lllllll}21 & 25 & 186 & 1248 & 1770 & 4.45 & 0.70\end{array}$

$(\%) \quad(\%) \quad(\%) \quad(\%) \quad(\%)$

$\begin{array}{ccccccc}15 & 15 & 57 & 693 & 2468 & 4.72 & 0.56 \\ (0 \%) & (0 \%) & (0 \%) & (21 \%) & (76 \%) & & \end{array}$

$\begin{array}{lllllll}1314 & 735 & 806 & 263 & 130 & 3.87 & 1.15\end{array}$

$\begin{array}{lllll}(40 \%) & (22 \%) & (25 \%) & (8 \%) & (4 \%)\end{array}$

$\begin{array}{lllllll}95 & 167 & 834 & 1304 & 851 & 3.81 & 0.98\end{array}$

$(3 \%) \quad(5 \%) \quad(26 \%) \quad(40 \%) \quad(26 \%)$

$\begin{array}{lllllll}14 & 30 & 180 & 1534 & 1490 & 4.37 & 0.67\end{array}$ 


\begin{tabular}{|c|c|c|c|c|c|c|c|c|}
\hline \multirow{3}{*}{$42^{*}$} & $\begin{array}{l}\text { orang lain biar bagaimanapun } \\
\text { pencapaian mereka. }\end{array}$ & $(0 \%)$ & $(1 \%)$ & (5\%) & $(47 \%)$ & $(46 \%)$ & & \\
\hline & $\begin{array}{l}\text { Saya merungut apabila ditimpa } \\
\text { penyakit. }\end{array}$ & $\begin{array}{c}934 \\
(29 \%)\end{array}$ & $\begin{array}{c}836 \\
(26 \%)\end{array}$ & $\begin{array}{c}932 \\
(29 \%)\end{array}$ & $\begin{array}{c}461 \\
(14 \%)\end{array}$ & $\begin{array}{c}87 \\
(3 \%)\end{array}$ & 3.64 & 1.12 \\
\hline & \multicolumn{6}{|c|}{ KESELURUHAN } & 4.26 & 0.36 \\
\hline
\end{tabular}

Paparan Jadual 1 merupakan dapatan analisis mengenai tahap amalan Islam dalam kalangan murid sekolah menengah. Dapatan kajian menunjukkan min keseluruhan bagi tahap amalan akhlak ialah 4.26 (sp.=0.36). Paparan pada jadual di atas adalah dapatan analisis mengenai tahap amalan akhlak murid Islam. Soalan-soalan yang dikemukakan adalah bagi melihat tahap amalan akhlak murid dalam menjalani aktiviti seharian mereka. Secara keseluruhannya, hanya dua item yang berada pada tahap sederhana iaitu Item 25 "Saya gemar mendengar lagu-lagu rentak terkini berbanding bacaan al-Quran" (M=2.64, Sp. $=1.17)$ dan Item 42 "Saya merungut apabila ditimpa penyakit" (M=3.64, Sp.=1.12). Manakala 40 item lain berada pada tahap tinggi. Item 35 "Saya takutkan azab Allah di dunia dan di akhirat" (M=4.81, Sp.=0.46) direkodkan sebagai item yang mendapat nilai min paling tinggi. Dapatan kajian juga menunjukkan min keseluruhan bagi tahap amalan akhlak ialah $4.26(\mathrm{Sp} .=0.36)$. Murid juga telah memberikan maklum balas terhadap beberapa item yang berkaitan dengan persekitaran sekolah mereka dan guru pendidikan Islam mereka.

Jadual 2: Persepsi Murid terhadap Persekitaran Sekolah

\begin{tabular}{|c|c|c|c|c|c|c|c|c|}
\hline & \multirow{2}{*}{$\begin{array}{l}\text { PERSEKITARAN } \\
\text { SEKOLAH }\end{array}$} & \multicolumn{5}{|c|}{ KEKERAPAN DAN PERATUSAN } & \multirow{2}{*}{ MIN } & \multirow{2}{*}{ Sp. } \\
\hline & & STS & TS & KS & $\mathbf{S}$ & SS & & \\
\hline 1 & $\begin{array}{l}\text { Persekitaran sekolah saya } \\
\text { menjadi panduan akhlak diri } \\
\text { saya. }\end{array}$ & $\begin{array}{c}88 \\
(3 \%)\end{array}$ & $\begin{array}{c}145 \\
(4 \%)\end{array}$ & $\begin{array}{c}726 \\
(22 \%)\end{array}$ & $\begin{array}{c}1473 \\
(45 \%)\end{array}$ & $\begin{array}{c}607 \\
(19 \%)\end{array}$ & 3.78 & 0.92 \\
\hline 2 & $\begin{array}{l}\text { Tindakan yang diambil } \\
\text { terhadap salah laku murid } \\
\text { melalui peraturan sekolah } \\
\text { mempengaruhi } \\
\text { pembentukan akhlak diri } \\
\text { saya. }\end{array}$ & $\begin{array}{c}66 \\
(2 \%)\end{array}$ & $\begin{array}{c}96 \\
(3 \%)\end{array}$ & $\begin{array}{c}444 \\
(14 \%)\end{array}$ & $\begin{array}{c}1586 \\
(49 \%)\end{array}$ & $\begin{array}{c}841 \\
(26 \%)\end{array}$ & 4.00 & 0.86 \\
\hline 3 & $\begin{array}{l}\text { Persekitaran sekolah saya } \\
\text { menjadi faktor pendorong } \\
\text { yang kuat untuk saya } \\
\text { mengamalkan sikap dan } \\
\text { tingkah laku berakhlak. }\end{array}$ & $\begin{array}{c}55 \\
(2 \%)\end{array}$ & $\begin{array}{c}105 \\
(3 \%)\end{array}$ & $\begin{array}{c}602 \\
(18 \%)\end{array}$ & $\begin{array}{c}1434 \\
(44 \%)\end{array}$ & $\begin{array}{c}838 \\
(26 \%)\end{array}$ & 3.95 & 0.88 \\
\hline \multirow[t]{2}{*}{4} & $\begin{array}{l}\text { Persekitaran sekolah saya } \\
\text { menjadi benteng untuk diri } \\
\text { saya dari melakukan perkara } \\
\text { yang tidak berakhlak. }\end{array}$ & $\begin{array}{c}232 \\
(7 \%)\end{array}$ & $\begin{array}{c}231 \\
(7 \%)\end{array}$ & $\begin{array}{c}628 \\
(19 \%)\end{array}$ & $\begin{array}{c}1260 \\
(39 \%)\end{array}$ & $\begin{array}{c}678 \\
(21 \%)\end{array}$ & 3.63 & 1.14 \\
\hline & \multicolumn{6}{|c|}{ JUMLAH } & 3.84 & 0.70 \\
\hline
\end{tabular}

Paparan pada jadual di atas menunjukkan bahawa item yang mendapat nilai min tertinggi ialah Item 2 iaitu tindakan yang diambil terhadap salah laku murid melalui peraturan sekolah mempengaruhi pembentukan akhlak diri murid $(\mathrm{M}=4.00, \mathrm{Sp} .=0.86)$. Ini menunjukkan bahawa tindakan yang diambil atas salah laku murid memberi kesan yang positif kepada mereka. Persekitaran sekolah saya menjadi faktor pendorong (Item 3, M=3.95, Sp.=0.88) dan panduan 
yang kuat untuk saya mengamalkan sikap dan tingkah laku berakhlak(Item 1, M=3.78, Sp.=0.92). Namun begitu, min yang rendah dilihat dalam Item 4 yang mana terdapat sejumlah murid yang merasakan persekitaran sekolah mereka tidak mampu menjadi benteng untuk diri dari melakukan perkara yang tidak berakhlak (Item 4, M=3.63, Sp.=1.14). Umumnya, nilai min keseluruhan bagi pengaruh persekitaran sekolah dalam pembentukan akhlak murid ialah pada tahap $3.84(\mathrm{Sp} .=0.70)$ iaitu masih berada pada agak tahap tinggi.

Jadual 3: Persepsi Murid terhadap Guru-Guru Pendidikan Islam

\begin{tabular}{|c|c|c|c|c|c|c|c|c|}
\hline \multirow{2}{*}{ BIL } & \multirow{2}{*}{$\begin{array}{l}\text { GURU-GURU PENDIKAN } \\
\text { ISLAM }\end{array}$} & \multicolumn{5}{|c|}{ KEKERAPAN DAN PERATUSAN } & \multirow{2}{*}{ MIN } & \multirow{2}{*}{ Sp. } \\
\hline & & STS & TS & KS & $S$ & SS & & \\
\hline 1 & $\begin{array}{ll}\text { Tingkah laku guru } \\
\text { Pendidikan Islam } & \text { saya } \\
\text { menjadi ikutan diri saya. }\end{array}$ & $\begin{array}{c}42 \\
(1 \%)\end{array}$ & $\begin{array}{c}139 \\
(4 \%)\end{array}$ & $\begin{array}{c}643 \\
(20 \%)\end{array}$ & $\begin{array}{c}1391 \\
(43 \%)\end{array}$ & $\begin{array}{c}1021 \\
(31 \%)\end{array}$ & 3.99 & 0.90 \\
\hline 2 & $\begin{array}{lrr}\begin{array}{l}\text { Maklum balas } \\
\text { diberikan } \text { oleh }\end{array} & \text { guru } \\
\text { Pendidikan } & \text { Islam } \\
\text { terhadap tingkah laku } \\
\text { saya mempengaruhi } \\
\text { pembentukan akhlak diri } \\
\text { saya. }\end{array}$ & $\begin{array}{c}27 \\
(1 \%)\end{array}$ & $\begin{array}{c}67 \\
(2 \%)\end{array}$ & $\begin{array}{c}364 \\
(11 \%)\end{array}$ & $\begin{array}{c}1587 \\
(49 \%)\end{array}$ & $\begin{array}{c}1191 \\
(36 \%)\end{array}$ & 4.19 & 0.78 \\
\hline 3 & $\begin{array}{l}\text { Guru Pendidikan Islam } \\
\text { menjadi faktor } \\
\text { pendorong yang kuat } \\
\text { untuk saya mengamalkan } \\
\text { sikap dan tingkah laku } \\
\text { berakhlak. }\end{array}$ & $\begin{array}{c}30 \\
(1 \%)\end{array}$ & $\begin{array}{c}52 \\
(2 \%)\end{array}$ & $\begin{array}{c}417 \\
(13 \%)\end{array}$ & $\begin{array}{c}1485 \\
(45 \%)\end{array}$ & $\begin{array}{c}1249 \\
(38 \%)\end{array}$ & 4.19 & 0.79 \\
\hline \multirow[t]{2}{*}{4} & $\begin{array}{l}\text { Nasihat guru Pendidikan } \\
\text { Islam menjadi panduan } \\
\text { daripada melakukan } \\
\text { perkara yang tidak } \\
\text { berakhlak. }\end{array}$ & $\begin{array}{c}259 \\
(8 \%)\end{array}$ & $\begin{array}{l}113 \\
(3 \%)\end{array}$ & $\begin{array}{c}212 \\
(6 \%)\end{array}$ & $\begin{array}{c}1410 \\
(43 \%)\end{array}$ & $\begin{array}{c}1242 \\
(38 \%)\end{array}$ & 4.00 & 1.14 \\
\hline & \multicolumn{6}{|c|}{ JUMLAH } & 4.10 & 0.66 \\
\hline
\end{tabular}

Melihat kepada peranan guru Pendidikan Islam dalam pembentukan akhlak murid pula, dapatan menunjukkan min keseluruhan berada pada tahap tinggi iaitu 4.10 (Sp.=0.66). Selain ibu bapa, guru Pendidikan Islam juga menjadi faktor pendorong yang kuat untuk murid mengamalkan sikap dan tingkah laku berakhlak (Item 2, M=4.19, Sp.=0.79). Maklum balas yang diberikan oleh guru Pendidikan Islam terhadap tingkah laku, murid mampu memberi kesan kepada pembentukan akhlak diri mereka (Item 3, M=4.19, Sp.=0.78). Nasihat guru Pendidikan Islam menjadi panduan kepada murid agar tidak melakukan perkara yang tidak berakhlak (Item 4, M=4.00, Sp.=1.14), namun segelintir mereka yang tidak dapat menjadikan tingkah laku guru Pendidikan Islam sebagai ikutan (Item 1, M=3.99, Sp.=0.90).

Ujian korelasi Pearson turut dijalankan untuk melihat tahap hubungan di antara pemboleh-pemboleh ubah yang dikaji. Untuk menentukan interpretasi nilai korelasi (r) yang dijalankan dengan cara interpretasi ujian Pearson Correlation yang dicadangkan oleh Julie Pallant (2007) seperti jadual beikut: 
Jadual 4: Interpretasi Nilai Pekali Korelasi

\begin{tabular}{lll}
\hline No. & Pekali Korelasi & Kekuatan Hubungan \\
\hline 1. & $\pm 0.70-1.00$ & Tinggi / Kuat \\
2. & $\pm 0.30-0.69$ & Sederhana \\
3. & $\pm 0.00-0.29$ & Rendah \\
\hline
\end{tabular}

Jadual 5: Analisis Hubungan antara Persekitaran Sekolah dan Guru dan Tahap Amalan Akhlak

\begin{tabular}{lcl}
\hline \multicolumn{1}{c}{ Pemboleh ubah } & r & Sig. \\
\hline Pengaruh Guru * Tahap Amalan Akhlak & .477 & .000 \\
Pengaruh Persekitaran Sekolah * Tahap Amalan Akhlak & .314 & .000 \\
\hline
\end{tabular}

$*$ Signifikan pada aras $\mathrm{p}<0.01$

Jadual di atas menunjukkan dapatan analisis kolerasi Pearson yang dijalankan bagi mengetahui korelasi antara pemboleh ubah pengaruh persekitaran sosial dan tahap amalan akhlak. Ini adalah kerana secara keseluruhannya pengaruh persekitaran sekolah dan guru dilihat dapat mempunyai hubungan positif yang signifikan amalan akhlak murid. Melalui paparan pada jadual di atas, guru-guru Pendidikan Islam ( $\mathrm{r}=.477$, sig.=.000) pula dilihat mempunyai dan boleh memberi pengaruh yang positif dalam membentuk amalan akhlak murid mereka, manakala persekitaran sekolah yang ada pula memberikan memberi kesan positif terhadap tahap amalan akhlak responden namun ianya berada tahap syang sederhana.

Dapatan kajian di atas juga telah melaporkan maklum balas daripada sampel kajian berkaitan aspek tahap amalan akhlak murid sekolah menengah. Bagi aspek amalan akhlak murid ini, secara keseluruhannya, hanya dua item yang berada pada tahap sederhana, manakala 40 item lain berada pada tahap tinggi. Ini menjadikan min keseluruhan bagi tahap amalan akhlak muridmurid ini berada pada tahap tinggi. Walau bagaimanapun, sedikit kebimbangan dari segi pembangunan akhlak kerana kajian turut mendapati nilai min sebahagian item berada di bawah 4.00 iaitu Item 15, 19, 25, 27, 31, 39, 40 dan 42. Bagi dua item terendah, "Saya gemar mendengar lagu-lagu rentak terkini berbanding bacaan al-Quran", dapatan menunjukkan min yang rendah disebabkan ramai murid kurang berminat dengan mendengar bacaan al-Quran berbanding dengan mendengar muzik kontemporari. Faktor ini mungkin disebabkan budaya mendengar muzik yang meluas dalam msayarakat dan media sosial terutamanya melalui Youtube, siaran radio dan juga saluran televisyen secara percuma atau berbayar. Apa yang membimbangkan, murid boleh terjerumus ke dalam kancah muzik liar yang boleh membawa keruntuhan akhlak mereka (Ahmad Munawar et. al. 2012; Ab. Halim et. al. 2016). Maka guru pendidikan Islam boleh meningkatkan kualiti pengajaran khusunya inovasi dalam pendidikan al-Quran (Wan Ali \& Nursafra 2018). Bagi menangani item "Saya merungut apabila ditimpa penyakit" pula, pelajar perlu dibimbing dengan program-program pembinaan rasa beragama dengan menekankan aspek pembangunan kerohanian yang dapat membentuk jiwa yang mensyukuri pemberian dan rezeki daripada Allah (Ahmad Tafsir 2007).

Dapatan ini menunjukkan masih terdapat sikap murid ini yang kurang sensitif terhadap perlakuan atau amalan akhlak dan nilai keagamaan dalam diri. Ini jelas memperlihatkan bahawa penghayatan akhlaknya tidak mencapai tahap yang lebih tinggi seperti yang diharapkan dalam objektif mata pelajaran Pendidikan Islam. Selain itu, item 14 (Saya melakukan hubungan seks) harus diberi perhatian lebih serius oleh guru-guru pendidikan Islam. Walaupun item ini memperoleh nilai min 4.74 iaitu berada pada aras tinggi, namun ianya belum mencukupi kerana ianya menunjukkan terdapat murid (15\%) yang mengambil ringan, tidak mengambil peduli dan mungkin juga mempunyai berkecenderungan untuk melakukan hubungan seks. Jumlah ini tidak boleh diambil ringan oleh pihak guru, sekolah dan ibu bapa walaupun jumlah murid tersebut tidak besar. Azhar (2010) juga mendapati isu yang sama dihadapi oleh segelintir murid iaitu 9.4\% 
daripada responden yang mengaku pernah melakukan hubungan seks. Jumlah ini amat membimbangkan dan boleh bertambah, dengan faktor dunia internet tanpa sempadan.

Bagi aspek persekitaran sekolah pula, beberapa aspek boleh diperingkatkan lagi kerana min bagi kesemua item berada pada tahap yang agak tinggi. Sebagai contoh, terdapat murid yang merasakan bahawa persekitaran sekolah tidak dapat mengekang mereka dari melakukan perkara yang tidak baik dan ada aspek dapat dijadikan panduan dalam amalan akhlak seharian. Kajian oleh Azhar (2010) juga mendapati trend yang hampir sama yang mana terdapat murid yang menyatakan persekitaran sekolah kurang memberi sumbangan kepada pengamalan tingkah laku berakhlak. Juriah \& Anuar (2015) menegaskan perancangan aktiviti pembelajaran yang pelbagai dan bersepadu untuk memenuhi keperluan pelajar yang mempunyai gaya belajar yang berbeza, keinginan mencuba idea serta pendekatan dan teknik yang baru seiring dengan persekitaran yang memberikan insipirasi. Suasana yang persekitaran sekolah yang positif di samping iklim sekolah yang bersifat melindungi mampu menjadi faktor pendorong yang kuat untuk murid mengamalkan sikap dan tingkah laku berakhlak (Ahmad Munawar et. al. 2018) seperti yang dinyatakan pada item 3 dapatan kajian ini.

Bagi aspek guru pula, secara umumnya kajian ini menunjukkan guru pendidikan Islam telah memberikan impak yang positif kepada amalan akhlak murid. Dapatan kajian ini selari dengan kajian yang dijalankan oleh Ab. Halim et. al. (2016) Dalam kajian ini, didapati pada pandangan murid, mereka mempunyai perspektif yang sangat positif terhadap guru-guru pendidikan Islam. Guru Pendidikan Islam dilihat sebagai contoh terbaik yang membentuk insan yang berakhlak dan bertaqwa. Efikasi kendiri juga perlu dipertingkatkan lagi kerana ianya memberikan kesan kepada peranan mereka sebagai agen perubahan dalam masyarakat (Noornajihan et. al. 2019).

Dengan itu, kajian ini menunjukkan hubungan guru pendidikan dengan amalan akhlak murid adalah adalah signifikan. Walaupun hubungan persepsi murid terhadap guru pendidikan Islam dengan amalan akhlak mereka pada tahap yang sederhana, kajian ini menunjukkan faktor guru dominan daripada ibu bapa adalah signifikan dalam mempengaruhi amalan akhlak murid. Kajian juga mendapati faktor persekitaran sekolah turut menyumbang kepada pengalaman akhlak murid. Berdasarkan dapatan kajian ini, dapat difahami bahawa peranan guru dan sekolah adalah penting dalam konteks pembangunan diri dan penghayatan akhlak murid. Kamarul Azmi et. al. (2009) menjelaskan bahawa para guru sangat disanjung kerana mereka bukan sahaja berilmu bahkan mestilah mempunyai personaliti dan komitmen kepada Islam dengan menunjukkan contoh yang baik kepada para murid supaya mereka boleh mengikuti guru mereka tanpa ragu.

Justeru, aspek pendekatan dan gaya pengajaran guru juga perlu disesuaikan dengan perkembangan semasa dan terkini dalam usaha memaksimum penguasaan dan penghayatan ilmu yang dipelajari. Menurut Ab. Halim \& Nik Mohd Rahimi (2010) tugas guru mengikut perspektif Islam merangkumi pelbagai tanggungjawab yang sangat luas dalam pembangunan akhlak dan diri manusia iaitu sebagai murrabi, muaddib bukan semata-mata seorang mu 'allim. Rosnani (1997) juga telah menghuraikan sebagai muaddib, guru bertanggungjawab dalam menerapkan adab (disiplin dalam pemikiran, fizikal dan rohani). Sehubungan itu, tugas guru perlu dikaitkan dengan tugas sebagai pendakwah.

Faktor yang mungkin menyebabkan guru pendidikan Islam mempunyai hubungan yang kuat juga disebabkan mereka merupakan golongan yang sudah dianggap sebagai orang yang mempunyai didikan agama sempurna dan menjadi ikon utama dalam masyarakat. Justeru, mereka dianggap oleh murid sebagai seorang yang boleh dijadikan contoh dalam menjalani kehidupan beragama dan kehidupan berakhlak. Murid akan lebih mudah terkesan terhadap ilmu yang disampaikan oleh guru pendidikan Islam yang menyayangi mereka serta memberi tunjuk ajar dengan penuh hikmah dan kesabaran serta sangat berpegang teguh kepada ilmu dan agama sama ada dari segi aspek kebiasaan harian, ibadat, adab dan panduan agama. Ini ditambah lagi dengan kaedah didikan yang paling tinggi dan berkesan dalam pendidikan akhlak Islam adalah melalui kaedah contoh ikutan (Abdullah Nasih Ulwan 1995; Ab. Halim Tamuri et. al. 2004). Secara 
keseluruhannya, persekitaran sekolah yang selamat dan kondusif serta adab dan keperibadian guru pendidikan Islam yang tinggi berupaya merangsang kecemerlangan sakhsiah dan akademik pelajar sekaligus menjadi penyumbang kepada kejayaan dan kemakmuran negara (Kamarul Azmi et. al. 2009; Ahmad Munawar et. al. 2018).

Secara keseluruhannya, kajian ini memberi gambaran bahawa Pendidikan Islam memberi kesan yang positif kepada amalan akhlak murid sekolah menengah. Tahap amalan akhlak mereka juga berada pada yang tinggi dan begitu juga dengan pandangan mereka terhadap persekitaran sekolah dan guru pendidikan Islam. Jelas dapat dilihat bahawa majoriti murid didapati mengamalkan apa yang telah disampaikan oleh guru. Dapatan juga menunjukkan mata pelajaran Pendidikan Islam telah memberikan kesan positif kepada akhlak murid dengan berada pada aras baik. Faktor aliran sekolah dan pencapaian dalam akademik juga memberikan kesan positif kepada amalan akhlak murid. Kajian ini juga mendapati faktor guru dan persekiatan sekolah kelihatan menjadi semakin penting jika dilihat hubungannya dengan pelaksanaan pendidikan Islam dan penghayatan akhlak pelajar. Konsep guru sebagai muddaris, muaddib, muallim, mursyid dan murrabi perlu difahami dan dihayati oleh setiap pendidik.

Akta Pendidikan 1966 (Akta 550).

\section{References}

Ab. Halim Tamuri. 2000. A study of the knowledge of akhlaq in the Malaysian secondary schools: With special reference to the Islamic Education. Tesis Ph.D. University of Birmingham.

Ab. Halim Tamuri, Adnan Yusopp, Kamisah Osman, Khadijah Abdul Razak, Shahrin Awaludin \& Zamri Abdul Rahim. 2004. Keberkesanan pengajaran dan pembelajaran Pendidikan Islam ke atas pembangunan diri pelajar. Laporan Penyelidikan Fakulti Pendidikan, Universiti Kebangsaan Malaysia dan Jabatan Pendidikan Islam dan Moral, Kementerian Pelajaran Malaysia.

Ab. Halim Tamuri \& Nik Mohd Rahimi Nik Yusoff. 2010. Kaedah Pengajaran dan Pembelajaran Pendidikan Islam. Bangi: Penerbit Universiti Kebangsaan Malaysia.

Ab. Halim Tamuri. 2015. Standardization of Islamic education excellence in the world. Proceeding International Seminar Islamic Education in Global Era. Lampung, Indonesia: Institut Agama Islam Negeri Raden Intan.

Ab. Halim Tamuri, Khadijah Abdul Razak, Mohd Aderi Che Noh \& Mohd Izham Hamzah. 2016. Persepsi murid-murid terhadap amalan guru pendidikan Islam di Malaysia. e-Jurnal Penyelidikan dan Inovasi. Edisi Khas. 3(2.1): 18 - 40.

Abdullah Nasih Ulwan. 1995. Pendidikan kanak-kanak dalam Islam. Terj. Syed Ahmad Semait, Vol 2. Pustaka Nasional: Singapura.

Ahmad Munawar Ismail. 2009. Pengaruh akidah dalam penghayatan akhlak pelajar-pelajar sekolah menengah kebangsaan di Malaysia. Tesis Ph. D. Fakulti Pendidikan, Universiti Kebangsaan Malaysia.

Ahmad Munawar Ismail, Wan Kamal Mujani Wan Mohd Hirwani Wan Hussain \& Noor Inayah Yaakub. 2012. The missing of moral entity in modern civilization: values and social aspects. Advances in Natural and Applied Sciences. 6(6): 985-994.

Ahmad Munawar Ismail, Mohamad Zaid Mohd Zin \& Muhd Najib Abdul Kadir. 2012. Broadcasting media, impact to Malay students behavior in Malaysia. Journal of Applied Sciences Research. 8(5): 2596-2600.

Ahmad Munawar Ismail, Wan Kamal Mujani \& Zaizul Abd Rahman. 2018. Maqasid syariah and safety aspects in infrastructure and health of education practices in Malaysia. International Journal of Civil Engineering and Technology. 9 (11): 384-394.

Ahmad Munawar Ismail, Wan Kamal Mujani \& Zaizul Abd Rahman. 2018. Elements of thinking, identity and legislation in education practices in Malaysia about Maqasid Syariah. International Journal of Civil Engineering and Technology. 9(10): 820-830.

Ahmad Tafsir. 2007. Ilmu Pendidikan dalam perspektif Islam. Bandung: Penerbit Remaja Rosdakarya. 
Ary, D., Jacobs, L.C. and Razavieh, A. 1996. Introduction to research in education. Orlando: Harcout Brace College Publishers.

Asmawati Suhid. 2003. Kesesuaian subbidang pembelajaran adab dab akhlak Islam KBSM menurut persepsi guru. Prosiding Wacana Pendidikan Islam Kebangsaan (Siri 3): Perkaedahan Pengajaran Pendidikan Islam: Antara Tradisi dan Inovasi. 94-105.

Azhar Ahmad. 2010. Strategi Pembelajaran Pendidikan Islam dan Penghayatan Akhlak. Kuching: Profes.

Burn, R.B. 2000. Introduction to Research Methods. London: Sage Publications

Cohen, L. and Morrison, K. 2000. Research methods in Education, 5th Edtion. London: Routledge Falmer.

Darraz, Muhammad Abdullah. 1987. Prinsip Akhlak Berdasarkan Al-Quran. Terj. Abdul Fatah Ibrahim, Mohd. Sulaiman bin Haji Yasin, Wan Amna Wan Yaacob \& Abdullah Md Zin. Kuala Lumpur: Dewan Bahasa dan Pustaka

Juriah Tahir \& Anuar Ahmad. 2015. Kreativiti dan Inovasi dalam Pengajaran dan Pembelajaran Sejarah Di Malaysia. Jurnal Teknikal dan Sains Sosial. 4(1): 11-24.

Kamarul Azmi Jasmi, Ab. Halim Tamuri \& Mohd Izham Hamzah. 2009, Sifat dan peranan keperibadian guru cemerlang pendidikan Islam (GCPI) dan hubungannya denganmotivasi pelajar. Jurnal Teknologi. 51(E): 57-71.

Kamarul Azmi Jasmi \& Ab. Halim Tamuri. 2017. Kaedah Pengajaran dan Pembelajaran Pendidikan Islam. Skudai: Penerbit UTM.

Kementerian Pendidikan Malaysia (KPM). 1990. Pukal Latihan KBSM. Kuala Lumpur: Percetakan Negara.

Kementerian Pendidikan Malaysia (KPM). 1996. Laporan Mesyuarat Jawatan Kuasa Mengkaji Kurikulum Pendidikan Islam. Ke Arah Pembentukkan dan Pengukuhan Akhlak Pelajar ke 2. Kuala Lumpur: Bahagian Pendidikan Islam dan Moral

Kementerian Pelajaran Malaysia (KPM). 2002. Sukatan pelajaran Pendidikan Islam KBSM.

Kementerian Pendidikan Malaysia (KPM). 2015a. Kurikulum Standard Sekolah Rendah (KSSR) Pendidikan Islam Dokumen Standard Kurikulum dan Pentaksiran Tahun 1.

Kementerian Pendidikan Malaysia (KPM). 2015b. Kurikulum Standard Sekolah Menengah (KSSM ) Pendidikan Islam Dokumen Standard Kurikulum dan Pentaksiran Tingkatan 1.

Kementerian Pendidikan Malaysia (KPM). 2016. Kurikulum Standard Sekolah Menengah (KSSM) Pendidikan Islam Dokumen Standard Kurikulum dan Pentaksiran Tingkatan 2.

Kementerian Pendidikan Malaysia (KPM). 2018. Kurikulum Standard Sekolah Menengah (KSSM) Pendidikan Islam Dokumen Standard Kurikulum dan Pentaksiran Tingkatan 4 dan 5.

Marhaiza Ibrahim, Ahmad Zubir Ibrahim,Selamah Maamor \& Aznita Samsi. 2015. Pengajaran dan pembelajaran (P\&P) ke arah melahirkan modal insan kelas pertama. E-Journal of Holistic Student Developmen. 2(1): 12-22.

Mohd Yusof Ali. 2010. Amalan akhlak sosial Islam dalam kalangan pelajar bermasalah disiplin telah dijalankan di sekolah menengah kebangsaan di negeri Pahang. Tesis Sarjana Pendidikan, Fakulti Pendidikan, Universiti Kebangsaan Malaysia

Noor Hisham Md Nawi. 2011. Konsepsualisasi Semula Kurikulum Pendidikan Islam. Tg Malim: Penerbit Universiti Pendidikan Sultan Idris.

Noor Hisham Md Nawi. 2018. Membentuk Manusiawi Melalui Pendidikan. Kertas kerja dibentangkan Simposium Kebangsaan Kecemerlangan Pendidikan Islam Dan Bahasa Arab 2.02018 anjuran Persatuan Intektual Muslim Malaysia pada 12 November 2018.

Nornajihan Jaafar \& Ab. Halim Tamuri. 2012. Asalib Tarbiyyah al-Tifl bi al-Hikmah fi Dhu i AlSunnah al-Nabawiyyah. Hadis. 2 (Julai): 7-28.

Noornajihan Jaafar, Nurul Asia Fasehah Muhamad, Ab. Halim Tamuri \& Nur Hanani Hussin. 2019. The significant correlation between self-efficacy and goal orientation with the role of Islamic education teachers as a society change agent. Journal of Research, Policy \& Practice of Teachers \& Teacher Education . 9(2): 30-38

Rohana Tan, Norhasni Zainal Abiddin \& Andi Suwirta. 2016. Faktor yang Mempengaruhi 
Penghayatan Akhlak Islam dalam Kalangan Belia di sebuah Institusi Pengajian Tinggi Awam Malaysia. INSANCITA: Journal of Islamic Studies in Indonesia and Southeast Asia. 1(1): 5566.

Rosnani Hashim. 1996. Educational Dualism in Malaysia. Kuala Lumpur: Oxford University Press. Rozmi Ismail, Nor Azri Ahmad, Fauziah Ibrahim \& Salina Nen. 2017. Pengaruh Faktor Individu, Keluarga dan Persekitaran Sosial Terhadap Tingkah Laku Penyalahgunaan Bahan dalam Kalangan Remaja. Akademika. 87(April): 7-16.

Zarin Ismail \& Ab. Halim bin Tamuri. 2007. Falsafah Pendidikan Kebangsaan dan wawasan pendidikan di Malaysia: Satu analisis perbandingan dengan Pancasila sebagai teras pendidikan di Indonesia. Dlm. Zamri Mahamod et. al. (Pyt), Pendidikan di Malaysia dan Indonesia: Satu Pengalaman di Riau. Bangi: Fakulti Pendidikan, UKM. 1-12.

Wan Ali Akbar Wan Abdullah \& Nursafra Mohd Zhaffar. 2018. Inovasi Pendidikan Islam Inspirasi dan Transformasi. Kuala Lumpur: Institut Terjemahan dan Buku Malaysia.

Wan Hasmah Wan Mamat. 1993. Pelaksanaan Pendidikan Moral di Sekolah: Matlamat dan Harapan. Kuala Lumpur: Bahagian Pendidikan Islam, Kementerian Pendidikan Malaysia. 